\title{
Digitally Post-Human: Living On and After
}

\author{
Nigel Wood (Loughborough University)
}

\begin{abstract}
:
Definitions of digital abound at the present time, but there is a thread amongst the most vital of these that questions the relevance of human agency and evaluative choice. If we follow where technological advances take us we come to the unsettling conclusion that 'machine reading' has usurped more analogue procedures and that algorithmic formulae have supplanted human judgement; the opportunities that new software provide can outstrip our imagination in framing research questions. Literary history, however, addresses how we might make sense of the One as well as the Many, and, when confronted by a string of wordor phrase-patterns, it is not that our findings speak for themselves; we have to conjure their value. This is exemplified by analysing where some digital searches might take us in relation to Shakespeare's The Merchant of Venice, basing the reading on all the repetitions of gentile/gentle, kind, and credit. The sensitive interrogation of the play's electronic text does point us to salient 'returns' and patterning signalled by following where the significant iterations of these words might take us, but what we make of these lines of enquiry eventually calls on human evaluation and volition.
\end{abstract}

Keywords: digital humanities, posthumanism, The Merchant of Venice, Michel Foucault, distant reading, Jorge Luis Borges, Hilary Putnam.

When a text quotes and requotes, with or without quotation marks, when it is written on the brink, you start, or indeed have already started to lose your footing. You lose sight of any line of demarcation between a text and what is outside it. - Jacques Derrida 2004: 67

Into the Post-Human

In 1999, when the post-human had barely established itself in the humanities, N. Katherine

Hayles's How We Became Post-Human staked out a territory that needed careful definition.

(We may be able to find ourselves within a state of being posthuman some time in the future but I can now find no clear punkt to indicate where a sense of moving on from the human 
might place us.) Guiding this epistemological shift was a surrender of the will to randomness and a care to avoid relying on notions of conscious agency and design. The control that humanism had assumed was a vital ingredient of the human was errant and ultimately misleading; the plenum of life led one elsewhere. There was much outside the text, assuming that 'a' text could exist in a unitary sense:

$[T]$ he very illusion of control bespeaks a fundamental ignorance about the nature of the emergent processes through which consciousness, the organism, and the environment are constituted. Mastery through the exercise of autonomous will is merely the story consciousness tells itself to explain results that actually come about through chaotic dynamics and emergent structures. (Hayles 1999: 288)

The persuasiveness of this position is mainly to do with where we start from; all hypotheses demand a certain notice and we are challenged by a desire for mastery through that channel. Notice these things, rather than those. Pattern snatched from randomness is allied to the presence/absence duality that threaded its way through much post-modern thought, but with a significant difference in Hayles's formulation: the medium inevitably forms the message and, once out of the bottle, its potent agency hails us, and its 'functionality' proves indispensable and unshunnable in the same way that we would rarely find a use for a typewriter once we discover a computer, and would only use Tipp-Ex as a bid for nostalgia. The digital and its technological promise of instant address and access accelerates an embrace of the contemporary, the nowness of communication, and a throw-away aspiration to leave much behind as historicist curios. Artificial life shakes our tree of analogies, too: not just the real/fiction axis, but also relevant/redundant, and - although Hayles is reticent in 1999 on this score - origins/results. To identify relevance is also to seek an almost domestic calm; to rely on a source-and-trace genealogy is to place any item in a train of succession freed of disorderly contingency. 
The several recent experiments whereby we forgo social media contact and are thrown back onto our own mental and spiritual resources have been well-documented (see, for instance, the summaries in Marsh 2016; Corona 2012; Spratt 2015; and Kinsley 2015). The confinement of reflection to just 280 characters for Twitter or the latent (and sometimes 'emergent') unease at predominantly - or completely - virtual friendships may still just be teething problems. In wider terms, we may find our capacity to locate decipherable narratives and to evaluate them under some sort of threat. In a vast plenum of library shelves, Jorge Luis Borges imagined a total library in his short story, 'The Library of Babel' that contained everything we need to know for survival (Borges 1998: 112-18). The problem is that - to the human eye - all appears random; order is constantly lost, yet this provokes the inhabitants to search for some centre or Ur-book where all would achieve sense. Like those hosts of monkeys typing, ${ }^{1}$ rational ordering is not to be expected soon; yet we might diligently search, believing in the quest in any case. Nonsense might just need the correct translator to render it comprehensible.

The availability of such bibliographical riches, conversely, robs an individual text of significance because there is no immanent code (above others) that should demand attention. The Librarians are desperate and some commit suicide. Some become prey to fetishes: the 'Purifiers' burn books they deem nonsense so as to reduce the threatening plenitude and to smooth the path in quest of the 'Crimson Hexagon', containing illustrated books so exceptional and powerful in their challenge to normal texts that they are said to invoke magical effects, exactly what the Purifiers fear. For some there must be a key or complete index that will ease the distrust of ultimate meaning, as if there were somewhere an Enigma machine (or God?) that opened the doors of knowledge. For those who wish to anthropomorphise these notions, there is the pursuit of the 'Man of the Book' who will supply answers and so dissipate anxiety. This inhuman predicament is allied to more recent 
anxieties about decipherability and value in general. Borges's bibliographical voyagers face a collapse of what Hilary Putnam (among others) has termed a collapse of the 'fact/value dichotomy' (see Putnam 2002, especially 111-34). There are tangible objects, books that invite interpretation, and yet that irritable reaching after certainty is futile. Ontologically, books disappear as their very number - encouraging an absence of 'real' differentiation or grasp of detail - is dazzling. The human mind recoils or becomes addicted to various theologies. We might now reflect upon the vanishing point of electronic archives, where the data can never be all captured, the conspectus never in secure focus. So value is an intervention and could be open to mass influences, not the rationalistic winnowing of truth from impression; truth is what is accepted to be so.

The sense of the 'human' that is in crisis here stems from a number of complex issues that crowd around the digital episteme (if that is the relevant term any longer). Control and evaluation are an ethical matter for the humanist; one is accountable for one's final conclusions and one convinces another through them, but could that simply be an effect of rhetoric? There is an answer to that in humanistic terms, for the focus now shifts to degrees of proof so that convictions may be affected. As far as literary analysis is concerned, the detail and support required for a Book Club review is far removed from a more professional perspective where liking and preference run in a parallel (but not directly connected) course and one attempts to provide a colder rationale for a text's meaning and status. How we establish any consistent and accountable template for such more detailed readings is the job of literary theory and that standard might translate into democratic awareness and possibly action. It is not inhuman to establish repeatable grounds for value and so appreciation, and it is not robotic to gather ever more data to help us with that. Just as we have survived the radical translations from codex to manuscript to paperback to e-books, so we must concede that the Human has a history, and one of reaction and negotiation. 
In a retrospective glance the post-human summons memories of Foucault's The Order of Things. In providing Man with a history - a start point - Foucault inexorably signalled 'his' death too. The break-up of the Classical episteme, where the resemblance immanent in rudimentary words directed the human gaze and embedded itself in language, passed agency to linguistic convention, the very means that shaped thought: 'The resemblance of the root to what it names assumes its value as a verbal sign only through the agency of the convention that brought men together and regulated their language of action so as to create a language. In this way, from within representation, signs are united with the very nature of what they designate, and the primitive treasury of vocables is imposed, in identical fashion, on all languages' (Foucault 1970: 106). This analogy failed to serve a more scientific need to classify not by etymology but by a series of functions, so a language of Action emerged and human possession, the reach of the transcendental subject that Kant noted, led to a grid of analysis. Thus it is that archaeology is Foucault's apt word for his method of digging below consciousness and - potentially - undermining its pre-eminence.

This apparent detour into Foucault is not as diversionary as it may seem. Several commentators on the digitally human have included his predicted death of the author as corroboration of the obsolescence of 'Man' and its positivist accents (see Hayles 192-8; Hammond 2016: 140; Kittler 1985: 28; Braidotti 2013: 23-9; Lane 2017: 55-6). Roland Barthes's own sense of the author runs alongside Foucault's and, in Mark Poster's lucid account, several results follow. The most significant for the digital age are those embedded in function and theology: authors become merely a classificatory system and their potentially God-like status is challenged as they are caught up (inevitably) in a system of linguistic and cultural sign-systems that pre-empt 'originality'. As Poster affirms, the author on the titlepage is extracted from the text, 'to remove from its obvious meanings his or her intentions, styles, concepts, rhetoric, and mind'. This challenges the 'analogue circuit' that establishes 
'mechanisms of property' which 'solidify a link between creator and object' (Poster 2001:

68). The obvious riposte to this reliance on Foucault is that any network theory is bound to be a matter of convention, an agreed base level of syntactical and semantic familiarity or competence. Unless we expect communication to be convention-lite, dwindling into the completely random and serendipitous, any user of language can have her/his use accounted for - at its most preliminary - by reference to the language system that is thereby manipulated. How compacted has this focus become though - and useful in most forms of literary analysis? Language might speak us, but the exact disposition of its 'styles, concepts, rhetoric' constitutes every individual item in one's chosen literary history. The crux of the philosophical problem of the One and the Many is that we need a sense of the general - at a level of genre or predictive historical context - before we can even begin to ascertain the identity of the One. The reverse is however also the case: how certain can we be of the impact and accuracy of the generalised Many if it cannot fully account for the singularity often heterodox - of the particular? In Matthew Jockers's aspirational account of the method of macroanalysis, close reading has little place in literary history, as it is 'not only impractical as a means of evidence gathering in the digital library, but big data render[s] it totally inappropriate as a method of studying literary history. ... The literary scholar of the twentyfirst century can no longer be content with anecdotal evidence, with random "things" gathered from a few, even "representative" texts' (Jockers 2013: 7, 8). There is much to recommend this view where literary history is concerned, but Jockers has excluded some significant areas where human judgement is not simply 'anecdotal evidence' and its operations consistent and theoretically feasible. When editing a literary or any other kind of text, the constitution of one of the historical items can be complex and one can confront archival remnants that demand an editor's best guess-work to produce a convergent narrative - a narrative that, indeed, can be challenged or even overturned once more relevant data is 
unearthed. Like Borges's librarians, one is perennially humble before what is not yet explicitly in the archive, but, unlike those benighted souls, one might note the value of arriving at a point where one might know where the guesses begin and where certainty might not be established. It is also not a requirement when re-reading Foucault to expect traces of where the Enlightenment project of 'Man' has morphed into the post-human. In that the human reader and creator has faced radical dislocations in the past to her/his approach to any text, there may have to be proof that this is not another irruption in a long succession but a truly radical epistemological (and ontological) break with the past.

Even the most cursory glance at advanced digital literary enquiries should convince us that there has been - methodologically - a fresh inspection of what we thought we knew. In the same sense that the Annales historiographical approach placed single events within a larger and indeed more significant series of events, Franco Moretti, inspired initially by Fernand Braudel, has attempted to dislodge single-authored forays from their hitherto formative and central role. Co-operation and quantitative laboratory work is necessary to achieve most digital ends, and Distant Reading - where 'distance is a condition of knowledge' involving a focus on 'devices, themes, tropes - or genres and systems' (Moretti 2000: 57) - is an understandable rallying-call. Frequently, the capacity of the human mind to frame the best procedures to comprehend the cycles of history is unequal to digital tasks, where technical advances can outstrip the reach of research questions (see in this regard Meyer and Schroeder 2015: 69-94; Lane 2017: 66-85, 108-18; and Burdick, Drucker, Lunenfeld, Presner, and Schnapp 2012: 128-37).

Surrendering to the machine is not always the easiest concession for a humanist. However, any history of humanism is also a history of change. It is of only limited use to emphasise the least resistant strain of humanism if one is determined to find its 'history' over. Thus, one can trace the weakness of a hopelessly analogue approach by way of anecdote and 
a vestigial hope of individual potency. There are other aspects of the human, however, that re-surface perhaps unexpectedly in quantitative research. The pamphlets that have emerged from Stanford's Literary Lab explore literary development/modification, casting a cold eye on canon formation (see https://litlab.stanford.edu/pamphlets). The sixth of these, by Franco Moretti, titled “"Operationalizing”: or, the function of measurement in modern literary theory' (December 2013) is candid in its provisional challenge to some theories. The idea that 'operationalizing' is breaking down a 'concept' in order to transform it 'into a series of operations' is, in numerical or diagrammatic terms, also a conversion of literary details into measurable functions or 'spaces' (Moretti 2013a: 4). Via network theory, the interaction of characters can be deciphered. By sensitive word-counting, the simple frequency of reference to individual items, be they characters or patterning of words or phrases, might be weighed. The role of the protagonist - be it Macbeth or Antigone - is often a matter of connection and effect. Connection can be measured ('how many scenes are shared by Macbeth with significant others?'; 'how many lines through soliloquy are shared directly with the audience?'), but effect is not always amenable to the kind of measurement here attempted. In two closely associated pamphlets, No. 11, 'Canon/Archive: Large-scale Dynamics in the Literary Field' by Mark Algee-Hewitt, Sarah Allison, Marissa Gemma, Ryan Heuser, Franco Moretti and Hannah Walser (January 2016), and No. 17, 'Popularity/Prestige' by J. D. Porter (September 2018), there is outlined a project to identify who is 'in' a canonical club by tracing the 'morphological signatures of canonicity' (Porter 2018: 1). For Algee-Hewitt et al. the move away from a consideration of a canon to an identifiable 'literary field' where novels are concerned (2016: 3-4) brings into the equation a collision between prestige and popularity, the former a product of patronage, the latter of a market. What interests the AlgeeHewitt group is how many 'fringe' authors there were - some with perhaps single texts to their name and therefore with projects that were one-offs and perhaps experimental, worth 
studying for their rarity value, yet who are not marked by the imprimatur, Sir Walter Scott or Jane Austen. What is left in the canon's shade is 'a vast wreck of ambitious ideals, very unlike the landscape literary historians are used to study. Learning to look at the wreck without arrogance - but also without pieties - is what the new digital archive is asking us to do...' (2016: 13). A synopsis of many of these positions can be found in Franco Moretti's 'Literature, Measured' (Moretti 2016; Pamphlet 12 [ April 2016]), where the thrill of new ventures is captured, the necessary laboratory collaboration explained, and the daring to face failure celebrated.

The aspirations of these methodologies are surely laudable, but the question remains as to whether the 'human' has been removed from the process, or, rather, how it has been augmented. For example, the proposition from N. Katherine Hayles that 'machine reading' has so disturbed our equipoise that it has introduced 'unsettling implications', that, for the first time 'can be construed as pointing towards a posthuman mode of scholarship in which human interpretation takes a backseat to algorithmic processes' (2012: 30), thereby needing careful analysis. The processes described in these pamphlets hit a point where interpretation amongst the plethora of available data - intervenes and it is derived from judgement. This evaluation is derived neither from anecdote nor piecemeal recollection and is modified significantly by what comes to notice via 'algorithmic processes', but - and this is nothing new philosophically - data is not collected via simple deduction: it is not 'there' in any ontologically pure form as it is produced by a utilisation of technology and is thus under the direction of human choice. J. D. Porter may well have a point when he describes the canon as a club (Porter 2018: 1-2), entry to which derives from a binary model: inclusion/exclusion; instead archival investigation involves us in a spectrum of possibilities or exceptions to canonical expectation. The problem with this is that one might simply delay the exercise of choice, and if that choice is constituted on a different model, then it does not move the 
'human' from the process. Hence it is that Porter admits he is led to consider that spectrum by reading Bourdieu, Goodreads, and the metric of those authors' 'presence ... as a subject of academic discussion' in the MLA community (Porter 2018: 4). Similarly, when assessing how canons are formed over time, he resorts to the 'H in DH' (Porter 2018: 20), a reaching out to a humanistic spectrum of interests within the digital; there are conscious reasons as well as ideologies in play. This is to say nothing about the 'prestige' axis, an assessment not of statistical data alone but rather of human behaviour where one's starting point is choice.

In the Algee-Hewitt et al. study, Braudel's Annales is acknowledged as is the partially determined influence on the algorithms of 'popularity' as well as 'prestige'. As a conclusion, the investigators turn to Niklas Holzberg's work on the novel and the significance of apparently 'fringe' formal traits (2003: 11-28). The facts do not speak for themselves. At crucial moments in Moretti's investigations, whilst 'Literary Theory' is challenged by empirical 'operationalizing', this set of conceptual tools - and how they are deployed - is in need of support from an overarching human value: we will see things differently and be better literary historians thereby. Derived from the projects allied to 'measuring' in history at large, the aims of Thomas Kuhn, Alex Woloch, and P. W. Bridgman are pressed into service to underpin the search for thematic paradigm shifts instead of simple numerical preponderance. 'Character space' does indeed differ from a protagonist's function overall in that simple repetition does not ensure thematic prominence; indeed, how themes strike a spectator or reader are complex matters. Ultimately, as Moretti notes in 'Literature, Measured', one's DH conclusions take root in soil already prepared by Theory and preexisting concepts. Ideally, a 'series of quantitative measurements enters into a dialogue with concepts, and slowly transforms them' (Moretti 2016: 5), leaving us with the inevitably human task of explaining the outcomes. 
In short, there is no escaping the heuristic power of Stanford's digital enquiries and their value in interrogating often only partially corroborated assumptions. No future literary historian will be properly equipped unless s/he comprehends how network theory can help us annotate particular texts and how we might properly come to terms with the embedded values that construct canon formation. One can easily foresee future curricula in the Humanities drop the coverage of some extra texts in favour of the inculcation of digital skills, and, as is happening now, senior/final year projects will have to take account of a spectrum of texts, not just those traditionally considered worth studying. This reflection upon the future of literary history is no longer new, but it might bear re-examining in relation to the tradition of reading.

\section{A Digital The Merchant of Venice}

In choosing a canonical example from Shakespeare's oeuvre, The Merchant Of Venice, one is perhaps falling foul of the prestige trap, but its advantage as a publicly available document is undeniable. Any analogue reading would note that there are noteworthy verbal repetitions that have often been fuel for interpretation. Kind and gentle/gentile mark out this text as possessing narrative-driven commentary on class and race. Another essay would require a sifting of the 1567 records of the word kind in the Early English Books Online (EEBO) database cited between the years 1560-1600 (the play probably emerges from 1596-97 due to contemporary allusions; the fullest account of dating the first performances can be found in Shakespeare 1987: 1-3). For gentle, a homophone of gentile for which there are no separate records on EEBO, there are 1074 records. One could sub-divide further significant semantic nuances or fields by taking the requisite pains. For example, kind points to meekness and charity as well as kinship, and gentile suggests non-Jewish as well as softness as well as well- 
bred. Within the play itself, there are twenty-seven repetitions of gentle and eighteen of kind. In no other text within the searched field do we encounter more than twelve repetitions of gentle and no more than ten of kind. Thematically, one might conclude, these foci are significant. In other words, the digital search confirms the unsubstantiated view that these are salient features of the play.

But where, however, might this lead us? Once we have located these frequencies, have we explored enough? The simple knock-down answer is 'No,' because the priority I have established is to reflect how an archive might bear upon an individual work, how one might trace complexities that are individual and precise. For example, repetition of words or gestures in performance are never a complete return to origins. If we are attentive, we might note the earlier reference but also register the journey between. The example of The Merchant of Venice ${ }^{2}$ is by way of exploring a consequence of this play of meaning that playtexts invite and exploit. This comedy has something of that via myths of Venice and early capitalism plus plot contours out of the Gesta Romanorum and Il Pecorone. It also in performance has a profound preoccupation with aspects of gentility/gentleness and also kith and kindness. In terms that resemble the portrayal of justice in Measure for Measure, the disguised participant in the working out of 'justice' is here not a Friar and not Balthasar as she appears, but Portia, armed with a few legal notes from the learned Bellario. The doubt as to whether the subverting of law is licit exists here too as the bond freely entered into by Antonio is rendered inapplicable by a too-literal reading of its terms and conditions. The comic frame of events comprises certain thematic offshoots that exist in echoes and allusions, more the product of memory than linear ordering. One is the repetition of kind both as an indication of class or race solidarity and also as a sign of courtesy and civilised behaviour and this conjoins with an analogous coming together of the genteel and the gentile. 
The first reference is broadly comic, Shylock's memory of the 'deed of kind' whereby Jacob benefited by the production of streaked lambs, a sardonic reference to Genesis 30:3743, where the popular belief that births were influenced by what mothers saw immediately before the event led Jacob to place before the ewes sticks that looked as if they were striped. By arrangement with Laban, this ingenuity apparently led to striped and spotted offspring that became Jacob's. This 'work of generation', however, is too basic and low an anecdote to appeal to Antonio, who regards it less as act of initiative on Shylock's part than a blasphemous ignorance of God's capacity for miracles (I.iii.83, 80). John Drakakis's note to this action in his 2010 Arden 3 edition succinctly draws together some of the wider implications of the thread: 'Kind here means 'nature' [OED, 4]; hence the modern idiom would be "doing what comes naturally". But where usury is considered a human interference with the natural order of things, the reference to nature here reinforces, through irony, Jacob's and, by extension, the Jew's propensity to interfere with its operations' (see Shakespeare 2010: 211). ${ }^{3}$ One could look further, however, for the term - especially as it gathers force by repetition throughout the play - is associated with neighbouring associations to $O E D 4$, such as $O E D$ 3: 'Nature in the abstract or viewed collectively'; 6b: 'The natural or proper manner of doing something'; II.6b: 'Of a person: of noble birth'; (as an adjective) 7b: ‘Affectionate, loving, fond'l and - less scientifically and neutrally - 8b: 'A class or category of things distinguished by common characteristics'. Procreation is basically a natural act, but - without any pre-knowledge of where the plot would go - witnesses to that first performance could register these cognate references simultaneously on that first enunciation. One does not have to wait too long to have that potential for significant punning to bear fruit, for the exchange between Shylock and Bassanio sixty lines later makes capital out of these related yet subtly alternative meanings; the bond to Shylock is 'kind' perhaps in the sense of 7b, yet Bassanio and Antonio in its iteration both introduce a pause to reflect on how being morally well- 
disposed and ethically correct might be an effect of race or tribe: Antonio agrees to 'seal' to the bond, concluding that 'there is much kindness in the Jew' (I.iii.153). Shylock wishes to 'show' kindness (I.iii.142). The temptation to choose clinically between the available semantic nuances is far more open to an analysis in the study than one based on performance, where one is serially registering echoes and possibilities.

Shylock's exit is met with a valediction from Antonio that reduces - but does not remove - some of that potential for double meanings: 'Hie thee gentle Jew./The Hebrew will turn Christian, he grows kind' (I.iii.176-7). The introduction of that homophone of 'gentle/gentile' reduces thematic possibility and uncovers the prejudicial use on the part of the Gentiles (at least) of 'kindness'. ${ }^{4}$ This confluence between courtesy and specifically Gentile behaviour is confirmed unequivocally by Gratiano when praising Jessica at II.vi.51: 'Now (by my hood) a gentle and no Jew'. The fact that Jessica has just stolen a casket of jewels to sustain her new Gentile life with Lorenzo supplies an extra-textual gloss on this commentary, and Jay Halio - for his Oxford edition - supplies the explicit reading here of 'gentile' (Shakespeare 1994: 147). This interested usage surfaces most prominently once more in the preliminaries of the trial scene, where (by now) one has recognised that any dictionary definition of kind/ness or gentility/gentleness might only tell part of this story. The Duke's invitation for Shylock to supply a 'gentle answer' in line with 'offices of tender courtesy' (IV.i.33-4) is refused by Shylock on a basis of Venice's 'charter' and 'freedom' (IV.i.39). Bad laws admit negotiation; the state relies on literal rulings. One is not apparently invited to be over-ingenious in reading or hearing Portia's famous praise of mercy later in the scene, for 'the quality of mercy' should descend upon us 'as the gentle rain from heaven' (IV.i.182-3) - but only 'apparently' or one might say 'traditionally', for by now the cluster of 'gentle/gentile' references has taken on a life of its own, freed from a local narrative context. As excerpted, the 'gentle rain' seems not to draw attention to, or derive power from, earlier 
uses, and, quite rightly editors use their annotational space to draw our attention to the biblical allusion at Deuteronomy 32:25; yet if one does indeed follow these texts to source, they add to a consciousness of the racial and religious divides played out before us in the scene.

The above citations are from passages where one might expect editorial help, as they regularly appear in critical readings as possessing some thematic impact. Yet taken as an auditory and public display, several other contributions to this thread should be noted. Thus, Salerio claims that 'A kinder gentleman [than Antonio] treads not the earth' at II.viii.35; Jessica is twice named as 'gentle' by Lorenzo at II.iv.19; at II.iv.34, Portia asserts that she stands before Bassanio just before he makes his choice of casket with a 'gentle spirit' (III.ii.163); and, just prior to his attempt at extorting a 'gentle answer' from Shylock, the Duke announces an agenda for 'human gentleness and love' (IV.i.24). By accretion, these sounds create an enlarged context for such patterns, irrespective of the character to whom they are assigned. Their recurrence often runs parallel to the narrative, partly arising out of the causes and effects of motive and consequence, but also, extraneously, imposed upon it and also quite aside from the consulted sources, principally Fiorentino's Il Pecorone, Boccaccio's Decameron, the Gesta Romanorum, and Gower's Confessio Amantis, Book 5. In adapting the known source-material, it is easily deduced that Shakespeare's text is more 'interrogative'; the ethical decisions that are embedded in Merchant are starker yet more complicated in consequence and motivation. Take the Fiorentino narrative: it portrays Portia as some Circe, who twice dupes Giannetto (the Bassanio figure) and gains the forfeit of his ship and the wealth aboard. She is directly implicated in his financial embarrassment that leads to the risk of usury. Ansaldo (Antonio) is not just protective of a friend in Giannetto but of an adopted son, and Shylock's precursor is faintly delineated, as a Jew, whose motivation is once more to do with the fame of having defeated the most eminent of 
Christian merchants than any settled racial or religious prejudice. There is no plea by Portia for the audience (and the Jew) to consider the claims of mercy in the trial scene, and there is no forced conversion. There are no other suitors, and no Jessica-Lorenzo love interest; there is also no rough-hewn commentary from Gratiano. There is a bride for Ansaldo, so the celebrations involve three couples and no singletons. The Dupe of the Italian title is doubled in the source: Giannetto as well as the Jew; in the later narrative, it is Shylock alone.

These allusions to recognisable sources do not determine the eventual range of meanings they accrue because Shakespeare's emendations are often paratactical and because he scattered such traces throughout his own work. The casket plot from Richard Robinson's translation of History 32 of the Gesta Romanorum rendered the test one for a lone female, the daughter of the king of Ampluy. Morocco and Aragon provide foils for Bassanio, but they also choose more logically than him. The gold, silver, and lead caskets are imported from the Gesta: questions of what one might most deserve and desire are indeed transposed between the gold and silver choices, but the most arresting change is the one that meets with success in selecting the leaden: instead of being swayed by what 'God hath disposid' (Bullough 1957-75: I, 514). Bassanio opts for the serendipity of hazarding 'all he hath' (II.vii.9); moreover, the route to the correct choice lies in not just avoiding the snares of 'ornament', but the superficies that taints true judgement in law, the 'gracious voice' that sways and seduces (III.ii.74, 76). Well may he dub the scroll that lies next to Portia's likeness a 'gentle scroll' (III.ii.139). Shylock has no latitude in his world for hazard - unromantic though it be, his bulwark against dissolution is a careful hoarding of monetary wealth, and this defensive posture is solely Shakespeare's invention:

You take my house, when you do take the prop

That doth sustain my house: you take my life

When you do take the means whereby I live. (IV.i.373-5) 
Additionally, one could argue that what Jessica and Lorenzo get up to once she flees her father's protection is spendthrift; what she gives over to her Gentile lover is not hers in any case. Shylock is allowed a (presumably sorely missed) wife, Leah, whose remembrance is annexed to the turquoise (III.i.113-15) casually bartered for a monkey. To the extent that there is here a counterpart to Marlowe's Abigail in The Jew of Malta we might draw a rather traditional distinction: Jessica elopes for love and liberty, and her father's wealth enables this separation whereas Abigail shows obedience by robbing the convent for her father, and throwing his sequestrated treasure down to him (II.i). ${ }^{6}$ It is not an insignificant detail that she dies taking Barabas's poison, and, in confession to Friar Bernardine, her last words confirm a wish to have her father converted, 'that he may be saved', and also that she dies a Christian (III.vi.39-40). By degree, this equivalence establishes a contrast between disobedient and obedient, fortunate and tragic, that marks Jessica's status as one who hazards rather than obeys and is rewarded because of it. Uncannily, this could be said to be one thematic strand of the action that works against its supposed ethical consistency; post-humanistically, it could be said to comment upon the critical hazarding of 'positions' in contemporary digital discourse. Too apt to construct themes and/or tropes on an anticipated narrative axis, analogue commentators miss (or fail to register) those repetitions that do not seem to 'fit' on a unitary basis.

The basic question posed by the action is whether Jessica has been successfully assimilated into the Belmont niceties of Gentile existence; her father has been constrained to convert. It is Antonio who first establishes this as a condition of 'justice' and it is (characteristically) Gratiano who celebrates this 'christening' as a calling to account for two 'godfathers' - in a sublunary sense, in reference to a jury, but in an eternal sense, to his account before God, the Father (IV.i.396), and so Shylock would seem to have been banished from the play with an act to go. Some twenty lines before the play's conclusion, however, he 
makes a virtual re-entrance via his 'deed of gift' that assures - forcibly - his daughter's future, and he is there recognised as the 'rich Jew'. Well might Lorenzo claim that thereby there has dropped into the action 'manna in the way/Of starved people' (V.i.292, 294-5). Conversion would appear not to have been complete in any basic public sense, and the parody of Gentiles sustained by financial 'manna' as the Israelites were by nutrition during their journey through the desert after their escape from Egypt (Exodus 16: 15-40) would be neutered if the gift came from a Christian.

The awkward question posed by this charity or good and unearned fortune is strengthened by reminding ourselves of Bassanio's success in the choice of caskets. Far from being the result of providential care, the choice of the leaden casket is more directly a result either of Portia's coded encouragement (the allusion to leaden clappers in the introit to the choice $)^{7}$ and/or Bassanio's characteristic liking for risk and hazard. This is explicit in the scroll he picks up out of the casket, wherein he finds that his reward is attained by choosing 'not by the view' (then how?) but 'Chance as fair and choose as true;...'. Such 'fortune' falls to him and (repeated) he might now 'hold [his] fortune for his bliss'. This adds up to his judgement that the scroll might indeed be 'gentle' (III.ii.131-5, 138). This clear emphasis on how fortunate he has been could be pinned to a sense that the less fashionable lead signifies a probity that a more superficial gold or silver does not, but Shakespeare's deliberate evasion of a providential cause - a predestined pattern that Bassanio cannot but obey - in order to stress the supposedly estimable ingredients of hazard and daring is plain. For Elizabethans all mercantile activity was accompanied by a similar calculated enterprise and perhaps the very title of the play has a symbolic resonance, be it in reference to either Antonio or Shylock. Indeed, the activity is rather more dramatised as risk on Antonio's part than Shylock's, for it depends on his argosies steering safely through sands and reefs, the 'shallows and ... flats' that Salarino imagines might be a cause of Antonio's melancholy, imagining the potency of a 
threat whereby wealth might be 'now worth this/And now worth nothing' (I.i.26, 35-6). Bassanio's risk is worth it - as it happens - and Antonio's too (eventually), but does the play's action endorse this wagering?

Allowing for the possibility that the action produces a cluster of meanings that jostle for our notice, the play has been linked with early commentaries on usury and its ethical impact. However, the approach that observes a move away from the landless fluidity of a Venice to the beautiful mountains and apparent security of successfully inherited wealth does not always tally with what could appear overly ingenious details in the fifth act. Who indeed is the merchant of the title? For all Antonio's determination to stand as his friend's supporter during the ring controversy, and participate in the action in Belmont, he will end the action as solitary in Venice as he started it: success as a merchant demands it. There is also the open question as to whether Belmont emerges as a truly open community.

The advent of successful capitalism for Elizabethans accompanied urban growth; playgoers were the recipients of that on a rather extended sliding scale. This selfconsciousness of how - very rapidly - the economic basis of life had altered feeds into the basic business foundations of public theatre (see Weimann 1992): access to drama through choice was a novel experience for authors as well as spectators. Not all the available generalisations about the ideologies founded on that tally with the sometimes awkward balancing act - spiritually as well as politically - that recent research has discovered. As T. H. Lloyd makes plain, the crisis in the location of economic value could spread to a questioning of where value in general might be located Lloyd 2000; see also Shepard 2000; Muldrew 1993; and in relation to city comedy, Kitch 2007). ${ }^{8}$ Credit as a usurer's term was at that time more continuous semantically with that of ethical judgement; as Nina Levine observes with reference to the Henry IV plays, Falstaff's Eastcheap culture allows us to consider 'holiday pleasure and commercial exchange' instead of 'patronage and privilege' 
(Levine 2000); whether Hal disowns this on his accession - and whether we applaud him for it if he does - is a central issue of Part II and Henry $V$.

What digital scrutiny of seldom traced word patterns brings to the fore are not necessarily extraneous. It is often considered that Elizabethan discourses on usury somehow impinge on audience reactions to the play. Indeed they do, but not always in a straightforward fashion and, thereby, some verbal echoes are made more prominent for us to note and explore. For Thomas Wilson, in his Discourse upon Usury by Way of Dialogue and Orations (1572), it is the charging of interest - in line with Exodus, 22:25 and Leviticus, 25:35 - that is the sin (especially as expressed by Wilson's Preacher figure), and is apt to threaten social instincts for the sake of individualist power. ${ }^{9}$ Such assumptions are not consistently biblical in that one could also turn to Deuteronomy 23:19, where usury might be permitted where strangers are involved, but that just shelves the problem as to whom one could term a brother. Just as often as Wilson is mentioned where contemporary notions of credit were concerned, there are as many references to Francis Bacon as some sort of counterbalance: his essay 'Of Usury' (1597) is secular in its orientation: licensing might defeat any 'discommodities' whilst maintaining a necessary flow of trade involving 'certain persons and in certain places of merchandising', a line of argument that resonates from the 1571 debate on the Usury Bill (13. Elizabeth, c. 8) - Bacon 1625: 240, 244).

It might perhaps be in line with an Englishman's view of Venice and a subsidiary contribution to its mercantile status. In Robert Wilson's The Three Ladies of London (1584), it is Lady Lucre who gains power over her other two 'Ladies', Love and Conscience, by calling on the wiles of Usury alongside Dissimulation, Fraud, and Simony. It is significant that Usury is English although of Jewish descent. Love reconciles herself to an arranged union with Dissimulation, but does not duck the punishments handed out to all three by Nemo, a judge whose aim is to restore order to society. Gerontius, a Levantine Jewish 
moneylender, contrary to type, is forthright and possesses a faithfulness to his own moral codes, whereas Mercadero, a Christian Italian merchant - the equivalent to Antonio - is devious, to the point at which he considers a conversion to Islam to avoid paying his debt to Gerontius. Venice is not a regular scapegoat for republican capitalism in the drama of the period. Set in Venice, the anonymous A Knack to Know an Honest Man (1596) has the rebellious daughter, Phillida, help two prisoners escape from the clutches of her father, the usurer, Servio, in order to do the right thing, and avoid a profiteering over the ransom of Orphinio and Zephenius. It is not a consistent dramatic convention, therefore, to portray the spiritual wealth of Christianity in Venice as superior to that of others, including Jewish business practices. Gentiles are as guilty.

At the same time as signalling a preoccupation with racial and class schisms, Shakespeare could also exhibit a concern over social divisions and the inability under normal conditions for a society so dependent on willing credit - of belief as well as finance - to police itself equitably. Friar Lawrence despairs of a Romeo who allows desire to rob him of his manhood, and likens such perversity to the shape-changing of a usurer, who 'abound'st in all,/And usest none in that true use indeed/Which should bedeck thy shape, thy love, thy wit' (III.iii.123-5). Prodigality - a waywardness that swerves from one's birthright - is thus also a risk-taking too and a threat to a settled economy in its older sense - of regularity and consistency.

For Walter S.H. Lim (2010), this commercialism of the spirit was more acceptable then than now. Merchants of the Venetian republic had to be 'aristocrats' through activity rather more than birth or more feudal expectations derived from class, a land-based opportunity for stability and ownership through the generations. This is part of an initial demarcation between Belmont and Venice, where the obligations of inheritance for Portia might offer a more soothing alternative to the fractious tensions of trade, yet such a schematic dichotomy does not eventually (as we shall see) serve to efface traces of the other even when 
many disagreeables would seem to have been banished in the last act. In the midst of the ring badinage, Portia holds Bassanio to account for his 'double self' by swearing on his basic faithfulness despite his forfeiting of the ring: 'Swear by your double self/And there's an oath of credit' (V.i.244-5). Antonio intervenes on his friend's behalf and his perspective is significant, for, having once lent his 'body' for his sake, he would now 'be bound again,/My soul upon the forfeit' (V.i.249, 251-2). His attempt at a new dedication to Bassanio will be spiritual, a bias on the semantic fulcrum away from the basely economic, where credit is based on a purely financial basis, towards a personal ethical consistency that lends content to belief and faith - the 'credit' given a trustworthy individual so that loans might be advanced. He had raised the money to fund Bassanio's venture on a similar, but not identical, basis at I.i.180, where he suggested that he exploit his 'credit' around the city even if it be 'racked' 'to the uttermost' (I.i.180-1).

The conjunction of economic and ethical senses met in that one word is and was linked in the business world: your financial clout is a measure of how plausible you are to others, and thus how, on the Rialto, how 'sufficient' one might figure - Shylock's term that knowingly confuses goodness with creditworthiness (I.iii.16-17). An audience's immersion in any representation is - perhaps in an unholy sense - equivalent to that. We are not influenced by financial calculation, but the semantic spectrum of the word, credit, extends and includes connotations of illusion and conviction. For Shakespeare, this contract with his theatre-going public is key. It produces the same problematic in The Winter's Tale, for example, where Leontes loses the battle for his own credit by insisting he receive confirmation of it from Antigonus and the Lords at II.i.157 where his wife's honesty seems to be in question. This same recourse to 'credit' is embedded in the appeal to the audience on as well as offstage at V.i.178 by the Lord, although he believes his own proof by sight and recognition is an adequate counterbalance. Indeed, the Third Gentleman recognises the power 
of 'an old tale' that might just convince even if 'credit' were 'asleep' (V.ii.63-4). This is not a case of responding decisively where semantics is concerned, for its full dramatic impact relies upon a profound punning or meaningful linguistic valency. Far from an accidental or even merely functional linguistic choice, at certain junctures there is a unshunnable reminder of its range of available semes and how the plot has served this complexity.

\section{A Humanistic Digital?}

We might have arrived at this point without digital means, but, if we had, and placed the play in a pattern or range of probability displayed in diagrammatic or statistical format, we might have found that we possessed an enhanced context of Jewish representation. But the admixture of this with tribal/class associations would not be readily traced without 'human' intervention to decipher a dramatic accretion in the action and in duration, a thread that provides a rope bridge between coloured phrases and words that only appear to be separated by their plot position.

This is not a final position, however, as work on separating styles and techniques over the period - and learning anew the networks of allusion and echo - is ongoing. The identification of 'prop-types' and their valencies from 1590 and 1609 by Hugh Craig and Brett Greatley-Hirsch (2017) will take time fully to digest as will the more sociological approach to lexes undertaken by Jonathan P. Lamb (2017). There is also a dynamism embedded in exploring the anticipated experience in a playtext that is provoking new forms of digital enquiry and that is quite foreign to that derived from most novels. One nuance that has, however, recently emerged in digital enquiry is the re-discovery of the cognitive unconscious. Amongst several alternative semes, N. Katherine Hayles modifies a more general sense of such drives by claiming that it is less an attribute than a 'dynamic unfolding 
within an environment in which its activity makes a difference'... (2017: 25). Normally, this would imply a choice between alternatives in order for interpretation to have any weight. This apparent return to human agency is not straightforward within this paradigm, however, as 'choice' is not exactly identical with 'free will' (in scare quotes) as it gestures towards 'programmatic decisions among alternative courses of action, much as a tree moving its leaves to maximise sunlight does not imply free will but rather the implementation of behaviors programmed into the genetic code' (Hayles 2017: 25). This nice distinction is at least a qualification of the claims made in 2012 that 'machine reading' had completely supplanted the human; yet the photosensitivity illustrating the limited 'choice' here is fraught with perhaps undesirable side-effects. The definition of archive or the constitution of a field of data - as an inevitable starting-point - is not a 'natural' phenomenon and, in that it is inextricably bound up with how results are identified and found relevant or not, it might direct the sphere of choice but it cannot be a substitute for it. Human choice has always been open to improved bases for choice, and sunlight does not act upon surfaces in an equivalent way to the evaluation necessary to react to words and thereby intentions. When experiments are set up it is not as inevitable as natural reactivity. 'To prove' implies that there is a humanly identified need for that proof to have resonance. In the real world the battles over global warming or fake news are not decided by simple reference to empirical evidence. One might wish that they were but as matters now stand they are not. It is an ethical issue that cannot be elided into automatic processes. It is not that human nature has not changed but rather that it now still exists; it is not that the machines do our thinking for us, but we now judge differently and less negligently - and that is a massive step forward. The trouble is crediting the application of large data by registering its impact on single items or limited series of items. The awkward exceptions and local sub-texts get minimised almost to extinction if the human is not called upon. Retroactively, we also need to question how the 
categories of data constituted by digital enquiry actually, when more closely inspected, actually hang together. One appearance of kind is not quite a facsimile of another, and gentle and its relation to gentility and thus to a politics of racial identity cannot be adequately registered within any patterns of mass data. The complexity of factors that emerge once ethics or effectiveness are understood we may as well call 'human'.

\section{Notes}

${ }^{1}$ Borges first mooted this idea in his essay, 'The Total Library' (1999: 214-16). The Infinite Monkey Theorem is probably set out in its earliest form by Émile Borel (1913).

${ }^{2}$ The edition used is The Arden Shakespeare: The Complete Works, ed. Richard Proudfoot, Ann Thompson, and David Scott Kastan, rev. edn (London: Thomson Learning, 2001).

${ }^{3}$ The contrast between the natural fertility of procreation and financial multiplication is part of the contrast between the intercourse of merchants and that of kind that Aristotle noted (Politics, I.x:4-5). See the exchange between Viola and Feste in Twelfth Night, where the latter's success in begging 'expenses' leads him to wait for perhaps additional funds from Viola: 'FESTE: Would not a pair of these have bred, sir? / VIOLA: Yes, being kept together and put to use' (III.i.50-1).

${ }^{4}$ There is a temptation to look too curiously just on the racial undertones of the 'gentle/gentile' homophone: see Adelman 2003 (especially p. 8), where the terms are regarded as mutually exclusive, where the racial divide is the only major consideration; the socially conservative association of ethical behaviour and Gentile existence is arguably the primary seme.

5 'My doctrine shall drop as the rain, and my speech shall distil as doth the dew, as the shower upon the herbs, and as the great rain upon the grass,, this refreshment specifically directed to the Jewish nation. Cf. Ecclesiasticus, 35:20: 'Mercie is seasonable in the time of affliction, as cloudes of raine in time of drought.'

${ }^{6}$ See Marlowe 2007. In Jonson's The Staple of News (1626; pub. 1631), Aurelia Clara Pecunia similarly is won by Pennyboy Cantor from the miser Pennyboy Senior but also Pennyboy Junior the equivalent of Bassanio, but whose spendthrift ways are more marked. Aurelia is not the prize Shakespeare creates in Jessica; attended by her nurse Mortgage and Statute and Band, her ladies in waiting, and Wax, her chambermaid, she is an epitome of an emergent capitalism; whether this deliverance redeems her from her opportunistic self is questionable.

${ }^{7}$ The ringing of 'fancy's knell' is pressed home by the repetition of 'Ding, dong bell' (III.i.71-2).

${ }^{8}$ The link between a prodigal's fate and usury is clear according to Thomas Nashe (1593) in his Christs Teares Over Jerusalem:-(1594): 'The Prodigall child in the Gospell is reported 
to have fedde Hogges, that is, Usurers, by letting them beguile him of his substance' (1613 ed., "The Prodigall -child is reported to have fedde Hogges, that is, Usurers, by letting them beguile him of his substance" (p. 101).

${ }^{9}$ It is not often the case that commentators look beyond Wilson's overall judgement against lending with interest; his opposition to some 'learned fathers' who distrust the 'great rich merchant' on devotional grounds is not typical, yet it depends on what one might call a merchant; even if allowing for an entrepreneur that makes 'gain of his money', it is licit for traders to 'use the certain and assured way than dangerously adventure the seas' (Discourse upon Usury [1572] pp. 184-5). Wilson may not therefore have an Antonio in mind.

\section{References}

Adelman, Janet, 'Her Father's Blood: Race, Conversion, and Nation in The Merchant of Venice', Representations, 81: 1 (2003), 4-30.

Algee-Hewitt, Mark, Sarah Allison, Marissa Gemma, Ryan Heuser, Franco Moretti, and Hannah Walser (2016), 'Canon/Archive. Large-Scale Dynamics in the Literary Field, Pamphets of the Stanford Literary Lab, No. $11<$ https://litlab.stanford.edu/LiteraryLabPamphlet11.pdf > (last accessed 28 January 2020).

Bacon, Francis (1625 [1597]), The essayes or counsels, ciuill and morall, of Francis Lo. Verulam, Viscount St. Alban (London: printed by John Haviland, for Anna Barret)

Barthes, Roland (1977 [1968]), 'The Death of the Author', in Image-Music-Text, trans. Stephen Heath (London: Fontana, 1977), pp. 142-8.

Bloom, Harold, Paul De Man, Jacques Derrida, Geoffrey H. Hartman, J. Hillis Miller (2004 [1979]), Deconstruction and Criticism, London: Continuum.

Borel, Émile (1913), 'Mécanique Statistique et Irréversibilité', J. Phys. Theor. Appl. (Paris), 3: 1, 189-96.

Borges, Jorge Luis (1998 [1941]), 'The Library of Babel', in Collected Fictions, trans. Andrew Hurley, New York: Viking Penguin, pp. 112-18.

Borges, Jorge Luis (1999 [1939]), 'The Total Library', trans. Eliot Weinberger, in Selected Non-Fictions, ed. Eliot Weinberger, New York: Viking Penguin, pp. 214-16.

Braidotti, Rosi (2013), The Posthuman, Cambridge: Polity Press.

Bullough, Geoffrey (1957-75), Narrative and Dramatic Sources of Shakespeare, 8 vols, London: Routledge and Kegan Paul.

Burdick, Anne, Johanna Drucker, Peter Lunenfeld, Todd Presner, and Jeffrey Schnapp (2012), Digital Humanities, Cambridge, MA: The MIT Press. 
Corona, Steve (2012), 'How 30 days without social media changed my life' < https://stevecorona.com/how-30-days-without-social-media-changed-my-life > (last accessed 28 January 2020).

Craig, Hugh and Brett Greatley-Hirsch (2017), Style, Computers and Early Modern Drama: Beyond Authorship, Cambridge: Cambridge University Press.

Derrida, Jacques (2004 [1979]), 'Living On', trans. James Hulbert, in Harold Bloom, Paul de Man, Jacques Derrida, Geoffrey Hartman, Deconstruction and Criticism, London: Continuum, 2004, pp. 62-142.

Foucault, Michel (1970 [1966]), The Order of Things: An Archaeology of the Human Sciences, trans. Alan Sheridan, London: Tavistock.

Hammond, Adam (2016), Literature in the Digital Age: An Introduction, Cambridge: Cambridge University Press.

Hayles, N. Katherine (1999), How We Became Post-Human: Virtual Bodies in Cybernetics, Literature, and Informatics, Chicago: University of Chicago Press.

Hayles, N. Katherine (2012), How We Think: Digital Media and Contemporary Technogenesis, Chicago: University of Chicago Press.

Hayles, Katherine (2017), Unthought: The Power of the Cognitive Unconscious, Chicago: University of Chicago Press.

Holzberg, Niklas (2003), 'The Genre: Novels Proper and the Fringe', in Gareth Schmeling (ed.), The Novel in the Ancient World, rev. edn, Leiden and Boston: Brill, pp. 11-28.

Jockers, Matthew (2013), Macroanalysis: Digital Methods and Literary History, Urbana: University of Illinois Press.

Kinsley, June (2015), ' 4 ways cutting out Social Media will encourage positivity in your life', Elite Daily, 21 September < https://www.elitedaily.com/life/life-without-socialmedia/1182279 > (last accessed 28 January 2020).

Kitch, Aaron (2007), 'The Character of Credit and the Problem of Belief in Middleton's City Comedies', SEL, 47: 2, 403-26.

Kittler, Friedrich A. (1985), 'Preface to Gramophone, Film, Typewriter', trans. Stefanie Harris, in Literature, Media, Information Systems: Essays, ed. John Johnston, Amsterdam: G+B Arts, pp. 28-30.

Lamb, Jonathan P. (2017), Shakespeare in the Marketplace of Words, Cambridge: Cambridge University Press.

Lane, Richard J. (2017), The Big Humanities: Digital Humanities/Digital Laboratories, Abingdon: Routledge. 
Levine, Nina (2000), 'Extending Credit in the Henry IV Plays', Shakespeare Quarterly, 51: 4, 403-31.

Lim, Walter S. (2010), 'Surety and Spiritual Commercialism in The Merchant of Venice', SEL, 50: 2, 355-81.

Lloyd, T. H. (2000), 'Early Investigations into Exchange and the Value of Sterling, 15581568', The Economic History Review, n.s,. 53: 1, 60-83.

Marlowe, Christopher (2013), The Jew Of Malta, ed. James R. Siemon, London: Bloomsbury.

Marsh, Sarah (2016), 'Does quitting social media make you happier? Yes, say young people doing it', The Guardian, 21 September < https://www.theguardian.com/media/2016/sep/21/does-quitting-social-media-makeyou-happier-yes-say-young-people-doing-it > (last accessed 28 January 2020).

Meyer, Eric T. and Ralph Schroeder (2015), Knowledge Machines: Digital Transformation of the Sciences and Humanities, Cambridge, MA: The MIT Press.

Moretti, Franco (2000), 'Conjectures on World Literature', New Left Review, 1: 54-68.

Moretti, Franco (2013a), Distant Reading, New York: Verso.

Moretti, Franco (2013b), 'Operationalizing; or, the Function of Measurement in Modern Literary Theory', Pamphlets of the Stanford Literary Lab, No. $6<$ https://litlab.stanford.edu/LiteraryLabPamphlet6.pdf > (last accessed 28 January 2020).

Moretti, Franco (2016), Literature, Measured, Pamphlets of the Stanford Literary Lab, No. $12<$ https://litlab.stanford.edu/LiteraryLabPamphlet12.pdf > (last accessed 28 January 2020).

Muldrew, Craig (1993), 'Interpreting the Market: the Ethics of Credit and Community Relations in Early Modern England', Social History, 18: 2, 163-8.

Nashe, Thomas ((-15943ł), Christs Teares Over Jerusalem 'The Prodigall child in the Gospell is reported to have fedde Hogges, that is, Usurers, by letting them beguile him of his substance' whereunto is annexed a comparative admonition to London. London: J. Roberts..

Porter, J. D. (2018), Popularity/Prestige, Stanford Literary Lab Pamphlet, No. 17, < https://litlab.stanford.edu/LiteraryLabPamphlet17.pdf > (last accessed 28 January 2020).

Poster, Mark (2001), What's the Matter With the Internet?, Minneapolis: University of Minnesota Press.

Putnam, Hilary (2004), The Collapse of the Fact/Value Dichotomy and Other Essays, Cambridge, MA: Harvard University Press. 
Shakespeare, William (1987), The Merchant of Venice, ed. M. M. Mahood, Cambridge: Cambridge University Press.

Shakespeare, William (1994), The Merchant of Venice, ed. Jay Halio, Oxford: Oxford University Press.

Shakespeare, William (2010), The Merchant of Venice, ed. John Drakakis, The Arden Shakespeare, Third Series, London: Bloomsbury.

Shepard, Alexandra (2000), 'Manhood, Credit and Patriarchy in Early Modern England, c. 1580-1640', Past \& Present, 167, 75-106.

Spratt, Vicky (2015), 'Here is what your life would be like without social media', Grazia, 19 November < https://graziadaily.co.uk/life/opinion/heres-life-like-without-socialmedia/ > (last accessed 28 January 2020).

Weimann, Robert (1992), 'Representation and Performance: The Uses of Authority in Shakespeare's Theatre', PMLA, 107: 3, 497-510.

Wilson, Thomas (15721613 [1572]), Discourse upon Usury by Way of Dialogue and Oratcions, for the better varietye, and more delite, of all those, that shall reade thys treatise. London: Richard Tottell. 